DOI: 10.1515/ijek-2017-0001

\title{
FIRMS' AGGRESSIVENESS AND RESPECTIVE PERFORMANCE: AN EMPIRICAL STUDY UNDER PAKISTANI SCENERY
}

\author{
Obaid Ur REHMAN \\ Lecturer at CFCBE, CECOS University, Peshawar Pakistan
}

\begin{abstract}
The study investigates capital structure of all non-financial listed firms on Pakistan Stock Exchange (PSX) for the period of 2008 to 2014. To test the relation between firm aggressive behavior and its performance, the study uses exponential generalized least square regression by employing control variables. Levin, Hadri and ADF test are used to know the stationarity of data. Furthermore different diagnostic tests like VIF, Weisberg test for heteroskedasticity and Breusch and Pagan Lagrangian multiplier test for random effects are used to check the data normality. Results of the study reveals that financial managers' aggressiveness regarding financial policy is negatively, while aggressiveness regarding investment policy is positively effecting the firm's performance. The study also found that with the passage of time, firms in Pakistan have been devastating their performance. That's why study found negative relation between firms' age and dependent variables.
\end{abstract}

\section{KEYWORDS}

Capital Structure, Firm's Performance, ROI, ROA.

\section{JEL CLASSIFICATION}

B26, D04, D22, F65

\section{INTRODUCTION}

Financial performance of the firm and its value is greatly affected by the design of its capital structure. The research work of Modigliani (1958) put light on determinants of capital structure and factors that affecting this decision. So the issue regarding working capital management is getting immense consideration after the Modigliani (1958) hypothesis. Various researcher work on this concept to reveal the main idea, which enriches literature in the following forms:

(a) Modigliani (1958) proposes that capital structure design has no relation with firm value

(b) Modigliani (1963) contended that interest expense is beneficial to the firm as it work as tax shield for the firm. So their study recommends high use of leverage in the capital structure.

(c) The point L in Figure 1 postulates the optimal capital structure position. If debt is furthermore boost from point $\mathrm{L}$, financial distress cost increases compare to leverage benefits. 
(d) This balanced association will supplementary be changed when taking into consideration the effect of other variables like agency conflicts, informational asymmetry, financial distress etc...

(e) The concluding concern of the study integrates the inclination of management towards financial preference selection (Myers 1984). By doing this, there is not full control in the finance manager hands plus there's sufficient equity balance for firm's robust solvency position.

(a)

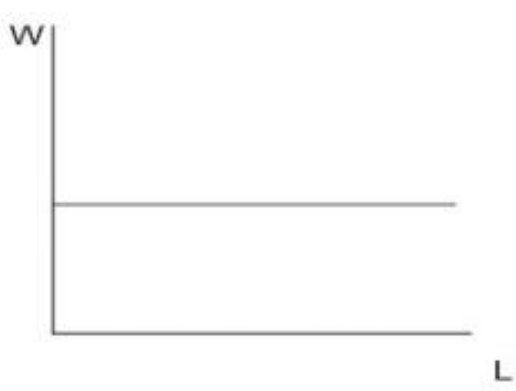

(d)

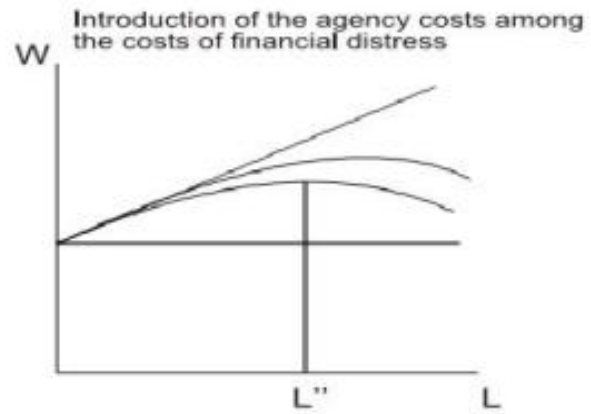

(b)

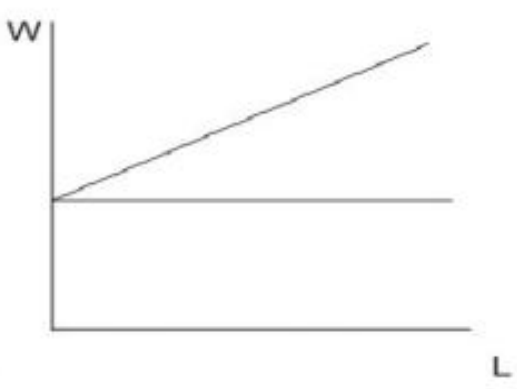

(c)

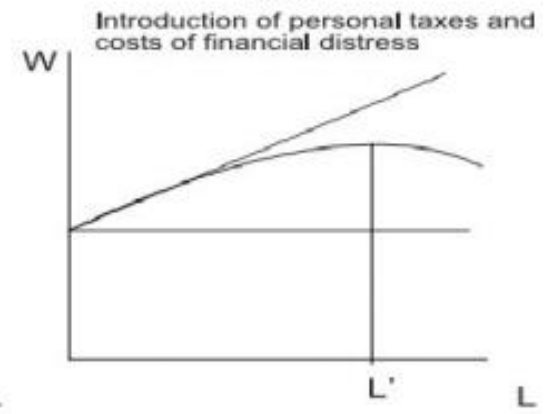

(e)

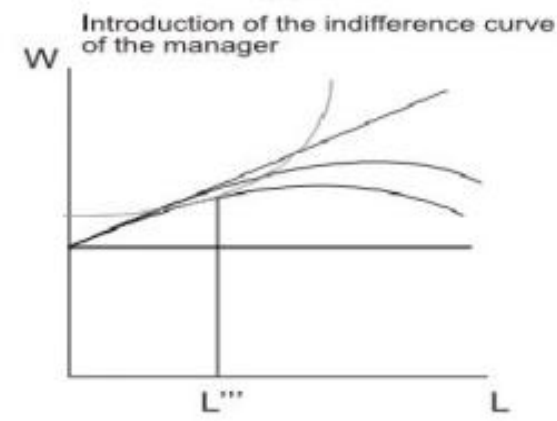

Key: W: firm value; L: leverage; L', L', and L',': optimal capital structure

Figure 1: taken from La Rocca, (2007)

Previous researches mainly study the working capital and its impact on firm performance (Harris, 1991; Rajan, 1995; Akhtar, 2005; Shah, 2007; Ezeoha, 2008 and Akhtar, 2009). However this study try to identify the manager aggressiveness regarding working capital management and its impact on firm operation in the long and short run.

\subsection{Problem statement}

From the past few decades, it has been observed from the literature that decisions of finance manager regarding working capital are generally overlooked. The problem structures its shape when finance manager aggressive decision regarding designing capital structure affecting the firm performance. The study attempts to identify such aggressiveness of finance manager while dealing with working capital during the business course.

\subsection{Research objectives}

The study attempts to analyze the finance managers' aggressiveness regarding handling working capital of the company at corporate level.

\subsection{Significance of the study}

In Pakistan, there are many factors which play vital role in effecting the firm performance or are uncourageous to the business environment like financial constraints awarded by the government 
impoverished infrastructure, political instability, low transparency position etc. Because of noised and inefficient market structure, it is very difficult for the firms (non-financial) listed on PSX to maintained optimum capital structure. In such scenario, the role of finance manager in any organization becomes tough as on one hand, he has to boost up the firm's worth by appreciated the firm's performance. The major intention of the research is to investigate the capital structure design effect on performance of the firm during the period of 2008 to 2014 in Pakistan.

\section{LITERATURE REVIEW}

\subsection{Conceptual Review}

One of the major rationales of fluctuating firm performance is the design selection of capital structure. Major use of leverage yield tax shield but also hoisting insolvency cost distress. So there's a capital structure mix in which tax shield marginal benefit is more than its bankruptcy cost. Harris (1991) contended that capital structure is associated to the balance between bankruptcy gain from both managers and shareholders and insolvency cost. Therefore because of more benefit of highest leverage ratio, it is beneficial to both managers and shareholders. Though literature take too lightly the liquidation overheads of bankruptcy or restructuring, or the united curiosity of shareholders and managers, which direct organizations to employs high leverage ratio than optimal in their capital structure.

\subsection{Theoretical Review}

\subsubsection{Irrelevant and Relevant Theory}

Modigliani (1958) postulates that firm's worth is impassive under certain assumptions like efficient market hypothesis, no transaction or impoverishment cost and taxation is irrelevant. It means choice of leverage is extraneous and external and internal finances are faultlessly alternate to each other.

\subsubsection{Agency Cost Theory}

Berle (1932) contended the relation between principal (shareholders) and agent (manager). This relationship came into notice when one or more principals hire one or more agents to work on their behalf in the company. This phenomenon creates opportunity for the manager to put their interest prioritized to principal's interest.

\subsubsection{Pecking Order Theory}

Developed by Allen (1993) assert that firm's financing needs decides the level of leverage. The theory postulates that typically companies used their retain earning at first in priority to sponsor their projects. Secondly company call for external debt and finally the alternative of issuing new share and generating equity is exercise to fuel their project engine. The theory is cited by Akhtar (2005), Ezeoha (2008), Rajan (1995), Shah (2007), Harris (1991), and Akhtar (2009) in their research work.

\subsection{Empirical Literature}

Literature exposes that many researcher work on working capital management but particularly the aggressiveness area is still vague in Pakistan. Gupta and Huefner, (1972); and Gupta (1969) apply variant financial ratios in working capital management among industries. Their study found variation among industry w.r.t. leverage, liquidity, profitability and performance. Johnson (1970) strengthens the previous work by indulging more samples using random effect test. Pinches et al., (1973) categorize different financial ratios using FCA and concluded that they're constant over the longer period. 
Various researchers contended that firm capital structure regarding current assets and current liability altered within industry eventually Soenen (1993); Ozkan, (2001); Harford et al., (2005) and Padachi, (2006). The significance of capital structure arrangement especially working capital is analyzed by Filbeck (2005) by considering manager policy of 32 non-financial listed companies in United State. Their study postulates a momentous variation found among industry sooner or later.

Association between conservative and aggressive working capital portion of capital structure is analyzed by Nazir (2009) by taking a total of 263 non-financial listed firms on PSX for the period of 1998 to 2003. Researchers employed LSD and ANOVA test for data analysis. The result shows variant outcomes regarding working capital aggressiveness and conservativeness transversely diverse industries in Pakistan. Furthermore, correlation test corroborated that divergence across industry is significant over 6 years. Researcher found adverse association between firm's profitability and aggressiveness in working capital management policies (AIP and AFP).

The study on hand updates the literature regarding aggressiveness in working capital impact on profitability of the company measured by ROI and ROA.

\section{METHODOLOGIES}

\subsection{Universe of the study}

The study is conducted for the rationale to provide a complete review about the relationship of the capital Structure design and its effect on firm performance. For this purpose, the study uses all nonfinancial listed companies domiciled at Pakistan Stock Exchange as universe of the study for the period of 2008 to 2014. A total of 527 firms are analyzed at first stage which is slimed to 267 firms after meeting the sample selection criterion which makes a total of 1869 observations. The whole population is taken as a census for the analysis.

\subsection{Sampling Design}

At first stage, 527 non-financial listed firms on PSX are selected whose financial secondary data is available for the study period i.e. 2008-2014. Following firms are excluded from the sample:

1. Banks, investment companies, and insurance companies as their capital structure are different from the non-financial sector firms, which possibly distort our analysis.

2. Incomplete data for study period

3. Firms those are suspended or delisted during the study period.

4. Firms having standard deviation more than 3 at any variable (dependent or independent)

Study Sample Selection

\begin{tabular}{|l|l|}
\hline Total indexed firms at first stage for the study period & 527 \\
\hline Less: Firms having incomplete data for the study period & $(162)$ \\
\hline Less: Firms with negative equity & $(77)$ \\
\hline Less: Firms having standard deviation more than 3 & $(21)$ \\
\hline Study sample for non-financial listed firms: & 267 \\
\hline
\end{tabular}

\subsection{Data Collection}

Data is collected from the state bank of Pakistan publications, balance sheet analysis of joint stock companies listed on Karachi stock exchange, financial highlights which are reliable sources of data 
in Pakistan. Furthermore data are also gathered from financial statements which exists in the annual reports downloaded from the company's respective websites of entire non-financial listed firms for the year 2008-2014 based on the subjective sampling.

\subsection{Justification of Variables}

Degree of firm's aggressiveness (in working capital) and its marginal role on overall performance (Weinraub, 1998) is the intent of the study. The study takes firm performance (ROI and ROA) as dependent while aggressiveness (AIP and AFP) as independent variables. In order to cop the more rationalization, the study employs major contributory variables to minimize standard error.

\subsubsection{Dependent Variable}

\begin{tabular}{|c|c|}
\hline \multirow{2}{*}{ (1) Return on Investment $(\mathrm{ROI})_{\text {it }}=$} & 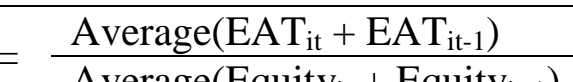 \\
\hline & Average $\left(\right.$ Equity $_{\text {it }}+$ Equity $\left._{\text {it- } 1}\right)$ \\
\hline \multirow{2}{*}{ (2) Return on Assets $(\mathrm{ROA})_{\text {it }}=$} & Average $\left(\mathrm{EAT}_{\mathrm{it}}+\mathrm{EAT}_{\mathrm{it}-1}\right)$ \\
\hline & Average $\left(\right.$ Asset $_{i t}+$ Asset $\left._{i t-1}\right)$ \\
\hline
\end{tabular}

\subsubsection{Independent Variable}

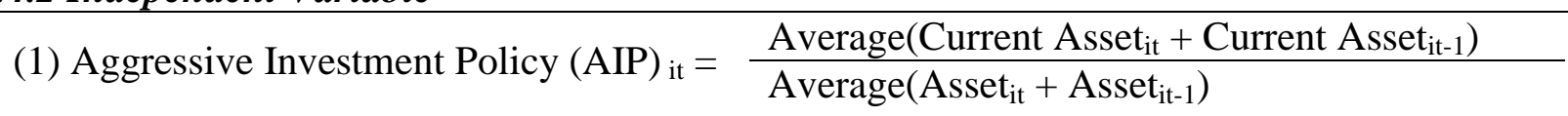
Lesser ratio indicates comparatively aggressive policy and vice versa

(2) Aggressive Financing Policy $(\text { AFP })_{\text {it }}=\frac{\text { Average }\left(\text { Current Liability }_{\text {it }}+\text { Current Liability }_{\text {it- } 1}\right)}{\left.\text { Average } \text { Asset }_{i t}+\text { Asset }_{i t-1}\right)}$

Lesser ratio indicates comparatively conservative policy and vice versa

\subsubsection{Control Variable}

Several researcher uses control variable in their studies while measuring firm performance (Smith and Begemann, 1997; Lamberson, 1995; Deelof, 2003; Teruel, 2005; Lazaridis and Tryfonidis, 2006 and Eljelly, 2004). The study on hand employs the following control variables to cope the elucidating aspects of firm performance which eventually curtail standard error. The study selected below mentioned control variables because they are not the major focus of the study but has major association with the dependent variables (Table 4.2).

\begin{tabular}{|c|c|}
\hline (1) Return on Equity $(\mathrm{ROE})_{\text {it }}=$ & $\frac{\text { efore Tax })_{\text {it }}}{\left.\text { uity }_{\text {it }}+\text { Equit } y_{\text {it-1 }}\right)}$ \\
\hline \multirow[b]{2}{*}{ (2) Return on Capital Employed $(\mathrm{ROCE})_{\text {it }}=$} & $(\text { Net Profit before Tax })_{\text {it }}$ \\
\hline & $\begin{array}{l}\text { Average (Capital Employed } \text { it }_{\text {it }}+\text { Capital } \\
\left.\text { Employed }_{\text {it }-1}\right)\end{array}$ \\
\hline \multicolumn{2}{|c|}{ (3) Growth of the firm $(\text { GROWTH })_{\text {it }}=\frac{\left(\text { Sales }_{\text {it }}-\text { Sales }_{i t-1}\right)}{(\text { Sales })_{\text {it }-1}}$} \\
\hline \multicolumn{2}{|c|}{ (4) Size of the firm (SIZE) $)_{\text {it }}=$ Logarithm of total assets } \\
\hline
\end{tabular}

ROE and ROCE is taken as control variable (Murugesu, 2013; and Zhang and Toppinen, 2011) because of scheming other than ROI and ROA variables. GROWTH, SIZE and AGE are taken as control variable because of the modified industry nature.

\subsection{Model Specification}

\subsubsection{Analytical framework and empirical model specification}

As the study is empirical nature and uses secondary data for analysis, it is the strength of the work to uses panel data for a longer period of time (2008-2014). In panel regression estimation, the data 
is doubly indexed (cross-sectional and time series) which making a huge data as sample of the study. Furthermore, panel data has the characteristics of controlling the endogeneity and heterogeneity problems. So the panel regression model analyzes the individual specific factor in different cross sections and in different time series of dependent variable with the independent variables (Hausman \& Taylor, 1981).

The fundamental structure of panel regression model is:

$Y_{i t}=\beta X^{\prime} i t+\alpha Z^{\prime} i+\varepsilon_{i t}$

In the above equation (1), the endogeneity is denoted by $X^{\prime}{ }_{i t}$ and the individual effect or heterogeneity is expressed by $Z_{t}{ }_{t}$ which postulates a stable and recognizable and non-recognizable variables. OLS evaluation supplies proficient and steady approximation of the original considerations (Kyereboah, 2007). Except when $Z^{\prime}{ }_{t}$ is non-recognizable and associated with $X^{\prime}{ }_{i t}$ then it need to use the other parametric tests because using of OLS in this situation will ultimately distort the fundamental objective of the analysis.

\subsubsection{Model specification}

From the literature, the study applies panel data analysis (fixed-effect, random-effect and OLS model) in order to analyze the depiction of capital structure on firm performance. The study has the following models in order to examine the hypothesis:

Firm performance $=f$ (Aggressive Investment Policy, Aggressive Financial Policy, Return on Equity, Return on Capital Employed, Firm Growth, Firm Size, Firm AGE)

\subsection{Firm performance measured by ROI}

\subsubsection{Pooled Regression Model}

$R O I_{i t}=\alpha_{0}+\alpha_{1} A I P_{i}+\alpha_{2} A F P_{i}+\alpha_{3} R O E_{i}+\alpha_{4} R O C E_{i}+\alpha_{5} G R O W T H_{i}+\alpha_{6} S I Z E_{i}+\alpha_{7} A G E_{i}+$ $\mathrm{E}_{1 i t}$

\subsubsection{Fixed Effect Model}

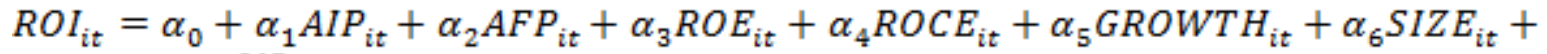
$\alpha_{7} A G E_{i t}+\sum_{i=1}^{267} \alpha_{i} i d u m+\varepsilon_{1 i t}$

\subsubsection{Random Effect Model}

$R O I_{i t}=\alpha_{0}+\alpha_{1} A_{I P} P_{i t}+\alpha_{2} A F P_{i t}+\alpha_{3} R O E_{i t}+\alpha_{4} R O C E_{i t}+\alpha_{5}$ RROWTH $_{i t}+\alpha_{6} S_{I Z E_{i t}}+$ $\alpha_{7} A G E_{i t}+\mu_{i}+\varepsilon_{1 i t}$

\subsection{Firm performance measured by ROA}

\subsubsection{Pooled Regression Model}

$R O A_{i t}=\alpha_{0}+\alpha_{1} A_{1} P_{i}+\alpha_{2} A F P_{i}+\alpha_{3} R O E_{i}+\alpha_{4} R O C E_{i}+\alpha_{5} G R O W T H_{i}+\alpha_{6} S_{I Z E_{i}}+\alpha_{7} A G E_{i}+$ $\varepsilon_{2 i t}$

\subsubsection{Fixed Effect Model}

$R O A_{i t}=\alpha_{0}+\alpha_{1} A I P_{i t}+\alpha_{2} A F P_{i t}+\alpha_{3} R O E_{i t}+\alpha_{4} R O C E_{i t}+\alpha_{5}$ GROWTH $_{i t}+\alpha_{6} S I Z E_{i t}+$ $\alpha_{7} A G E_{i t}+\sum_{i=1}^{267} \alpha_{i} i d u m+\varepsilon_{2 i t}$

\subsubsection{Random Effect Model}

$$
\begin{aligned}
& R O A_{i t}=\alpha_{0}+\alpha_{1} A I P_{i t}+\alpha_{2} A F P_{i t}+\alpha_{3} R O E_{i t}+\alpha_{4} R O C E_{i t}+\alpha_{5} G R O W T H_{i t}+\alpha_{6} S_{I Z E_{i t}}+ \\
& \alpha_{7} A G E_{i t}+\mu_{i}+\varepsilon_{2 i t}
\end{aligned}
$$




\section{DATA PRESENTATION, ANALYSIS AND INTERPRETATION}

\subsection{Introduction}

The study analyzes the data on hand in two major parts. In first part, data is expressed using descriptive analysis. While in the second part, data is empirically examined using inferential analysis using variant statistical software packages like EView, STATA and Gretl.

\subsection{Interpretation and Analysis of Data}

\subsubsection{Descriptive Statistics}

This part shows the general nature of data on hand for analysis purpose like mean, Std. Dev., minimum and maximum etc...

Standard deviation value of all the variables in Table 4.1, Appendix exposes that data used in the study is normally distributed. ROI and ROA values are asymmetrically distributed with a long tail moving towards left. It means firms in Pakistan are recurrently gaining little and few extreme losses. The Kurtosis values of ROI and ROA crossing the high degree of leptokurtic.

\subsubsection{Correlation Analysis}

Table 4.2, Appendix exposes the correlation analysis among variables (dependent and independent) of the study. Correlation analysis (Table 4.2, Appendix) postulates that there is high degree of association among return proxies of the study. The study found slight negative impact of aggressive financial policy on firms return. Growth has no concern with the firm performance (ROI and ROA) while Age is statistically significant with ROA while show no association with ROI.

\subsection{Test of Hypothesis}

\subsubsection{Regression Analysis}

This part of the study analyzes the panel data on hand to reveal the effect of explanatory variables on performance of the firm in Pakistan for the period of 2008 to 2014. The research work employs OLS model considering identical intercept overtime. The analysis also indulges the consideration of variant intercept for every firm in Pakistan by conducting fixed-effect model and random-effect model.

\subsubsection{Capital Structure and firm performance measured by ROI}

Table 4.3, Appendix exposes the relation between capital structure and firm's performance (ROI) in Pakistan for the period of 2008 to 2014 . The $p$-value of $F$-statistics $645.68(0.000<0.05), 245.93$ $(0.000<0.05)$ and $4287.58(0.000<0.05)$ contended that all the independent variables are mutually statistically significant at pooled-model, fixed-effect model and random-effect model in explicating deviation in the firm's performance in Pakistan. The $p$-value of Hausman test (0.000) postulating that difference in fixed-effect and random-effect models coefficients is systematic. So the study accept the alternative hypothesis thus acknowledge and infer the fixed-effect model for data analysis, which contradicting the study of Lawal, (2014).

Fixed effect model organize the lost variables that are variant in cases while constant overtime. This let the data alter overtime and exposing independent variable impact on dependent variable.

$Y_{i j}=\alpha_{j}+\beta X_{i j}+\varepsilon_{i j}$

For $i$ cases within $j$ group

Therefore $\alpha_{j}$ is a separate intercept for each group

It is equivalent to solely at within group variations: 
$Y_{i j}-\bar{Y}_{j}=\beta\left(X_{i j}-\alpha_{j} \bar{X}_{j}\right)+\varepsilon_{i j}-\bar{\varepsilon}_{j}$

$\mathrm{X}$-bar-sub-j means of $\mathrm{X}$ for group $\mathrm{j}$, etc.

Model is within group because all the variables are centered on mean of each group.

The results at Table 4.3, Appendix exposes that firm's aggressive policy regarding investment has statistically positive impact on firm performance. While aggressive financial policy negatively impacts the firm performance. It means firms in Pakistan if uses more fixed liability instead of current liability, it'll perform better. On the other hand, if firms put into practice high degree of current assets, it has positive impact on its performance. Furthermore; all the other control variables (except ROE and SIZE of the firm) negatively effecting the firm performance. ROCE and AGE shows negative and statistically non significance with respect to ROI in measuring firm performance.

\subsubsection{Capital Structure and firm performance measured by ROA}

Table 4.3, Appendix exposes the connection between capital structure design and firm's performance (measured by ROA) in Pakistan for the period of 2008 to 2014 . The $F$-statistic $p$-value postulates that $388.96(0.000<0.05), 164.56(0.000<0.05)$ and $1958.97(0.000<0.05)$ contended that all the independent variables are strongly statistically significant at pooled-model, fixed-effect model and random-effect model in explicating variation in the firm's performance in Pakistan. The $p$-value of Hausman test (0.000) postulating that difference in fixed-effect and random-effect models coefficients is organized. So the study accept the alternative hypothesis, which means fixedeffect model fit for data analysis, which is also contradicting with the study of Lawal et al., (2014).

The results at Table 4.3, Appendix exposes that firm's aggressive policy regarding investment has statistically positive impact on firm performance. While aggressive financial policy negatively impacts the firm performance. It means firms in Pakistan if uses more fixed liability instead of current liability, it'll perform better. On the other hand, if firms put into practice high degree of current assets, it has positive impact on its performance. Furthermore; all the other control variables (except GROWTH and AGE of the firm) has positively affecting the firm performance. AGE shows negative and statistically non significance with respect to ROA in measuring firm performance.

Table 4.4 postulates the Levin-Lin-Chu panel unit root testing at level (1) and at first difference.

The hypotheses of unit root testing are:

H0: Panels contain unit roots

H1: Panels are stationary

The $p$-value of dependent and independent variables contended that all the variables are stationary at level and first difference. While the Hadri LM stationary test postulates that ROI data contain unit root at level (1) and at first difference, it is stationary. After this, the study run the panel cointegration model because the pre-condition of panel co-integration model is the variable must unit root at level but when converted into first difference, then it will become stationary. Hadri LM test can fulfill the condition of panel co-integration model, so it can be considered as benchmark of the study. The result in Table 4.4, exposes that except D_ROI, all the other variables at level (1) and at first difference contains some unit roots because of the longer period of time and high number of cross sections. 


\section{SUMMARY, CONCLUSION AND RECOMMENDATIONS}

\subsection{Summary}

The research is about to find the finance manager's aggressive and conservative behavior regarding restructuring the capital structure of the firm (esp. working capital). The study try to find (in the context of Pakistani setting) that what style of manager's are successful in boosting the firm's performance.

The numerical findings gauge the finance manager aggressiveness and put in the existing literature that such behavior shows favorable impact on investment policy. But with the passage of time, such policy need to be reconstructed otherwise it'll shows unfavorable outcomes in the long run.

Finance managers' aggressiveness in working capital holding financial policy shows unfavorable outcomes. But, in the long run, such decision shows fruitful results. The reason behind this comprises of some behavioral partialities like fresh or unexperienced manager when take one fruitful decision, their next decisions are based on less rationality due to overconfidence. But with the passage of time, they faces many such bad experiences and are trained to cope with such kind of problems (Jensen and Meckling, 1976).

The study found that finance managers' aggressiveness regarding investment policy in the short run, while conservativeness regarding financial policy in the long run shows favorable outcomes in Pakistan. The above hypothesis is tested and verified in the study and it is found that decision of the finance manager is successful up to $51.91 \%$ in the investment policy and $41.94 \%$ in the financial policy (Table 4.3).

\subsection{Conclusion}

The novel consequences of this study is important to manage the investment and financial policy of all non-financial listed firms in Pakistan. The study discloses the relation between dependent variables (ROI and ROA) and independent variables (AIP and AFP). A sample of 267 non-financial listed firms from all sectors of PSX (after meeting the sample selection criterion) for the period of 2008 to 2014 making a total of 1869 observations. Pearson correlation (2-tailed at 5\% significance level) (Table 4.2, Appendix) reveals that AFP is negative and significant while AIP is positive and significantly associated with dependent variables. All the control variables are positively and statistically significantly associated (at $5 \%$ level of significance) with the firm performance except AGE in case of ROI.

The findings of the study reveal that aggressiveness of the finance manager regarding current liability adversely affecting the firm's performance. It means in designing capital structure of Pakistani non-financial listed firms on PSX, finance manager needs to be conservative regarding short term financial policy. Elaborately when increasing in the company's short term debt compare to its total assets yields negative results on firm's performance in Pakistan $(-26.6 \%$ in case of ROI and $-20.3 \%$ in case of ROA).

On the other hand, aggressiveness regarding firm's investment policy postulates a positive impact on overall performance of the firm (seen from AIP respective coefficient). It means Pakistani nonfinancial firms when designing the capital structure employee the current assets on maturity financial policy basis, it yield fruitful results in the short run. It is also observed from the results in Table 4.3, Appendix that with the passage of time, firms in Pakistan devastating their performance. 
That's why study found negative relation between firms' age and ROI (-25.4\%) and ROA $(-17.8 \%)$.

Hausman test score favor to pick fixed effect model for data analysis ( $p$-value $=0.000$ from Table 4.3, Appendix) in case of ROA. The study found that ROA is adversely affected when firms in Pakistan increase their long term debt compare to capitalization or their leverage ratio. The study found that as the time passes, Pakistani firm's performing well which is displayed in the form of favorable statistical significance in the Table 4.3, Appendix. Leverage ratio has little concern with the firm's performance (ROA).

\subsection{Recommendation}

From the above findings, the study recommends certain actions directing the corporate governance and finance manager of the companies in Pakistan. Most of the firms in Pakistan finance the tangible fixed assets by short-term debts. Regarding short-term debt, this research work found unfavorable results with the firm performance (in both ROI and ROA cases). So the study recommends analyzing a scale on which aggressiveness of the finance manager regarding funding postulates negative impact on firm performance.

The research work gave direction to finance manager that if he want to create firm value and boost up its performance in the market, it need to design an optimal capital structure which congruence the firms current assets with the maturity matching policy.

\section{REFERENCES}

Akhtar, S. (2005). The determinants of capital structure for Australian multinational and domestic corporations. The Australian Graduate School of Management, 30, 321-341.

Akhtar, S. and Oliver, B. (2009). Determinants of capital structure for Japanese multinational and domestic corporations. International Review of Finance, 9, 1-26.

Allen, D. E. (1993). The pecking order hypothesis: Australian evidence. Applied Financial Economics, 3(2), 101-112.

Berle and Means, (1932). The Modern Corporation and Private Property. Volume 1, Issue 4, 36-47 ISSN 2291-4471.

Deloof, M. (2003). Does working capital management affect profitability of Belgian firms?. Journal of business finance \& Accounting, 30(3-4), 573-588.

Eljelly AMA (2004). Liquidity Profitability Tradeoff: An Empirical Investigation in an Emerging Market. International Journal of Commerce and Management 14(2): 48-61.

Ezeoha, A. E. (2008). Firm size and corporate financial leverage choice in a developing economy. The Journal of Risk Finance, 9(4), 351-364.

Filbeck, G., and Krueger, T. M. (2005). An analysis of working capital management results across industries. American Journal of Business, 20(2), 11-20.

Gupta, M. C. (1969). The effect of size, growth, and industry on the financial structure of manufacturing companies. The Journal of Finance, 24(3), 517-529.

Gupta, M. C., and Huefner, R. J. (1972). A cluster analysis study of financial ratios and industry characteristics. Journal of Accounting Research, 77-95.

Harris, M., and Raviv, A. (1991). The theory of capital structure. The Journal of Finance, 46(1), 297-355.

Hausman, J. A., \& Taylor, W. E. (1981). Panel data and unobservable individual effects. Econometrica: Journal of the Econometric Society, 1377-1398.

Jensen M. and Meckling W. (1976). Theory of the Firm: Managerial Behavior, Agency costs and Ownership Structure. Journal of Financial Economics 3, 305-360. 
Johnson, William A., 1970, Default administration of corporate trust indentures: The general nature of the trustee's responsibility and events of default, St. Louis University Law Journal 15, 203-236.

Kyereboah-Coleman, A. (2007), "The impact of capital structure on the performance of microfinance institutions", Journal of Risk Finance, Vol. 8 pp.56-71.

La Rocca, M. (2007). The influence of corporate governance on the relation between capital structure and value. Corporate Governance: The international journal of business in society, 7(3), 312-325.

Lamberson, M. (1995). Changes in working capital of small firms in relation to changes in economic activity. American Journal of Business, 10(2), 45-50.

Lawal, A. I. (2014). Capital structure and the value of the firm: evidence from the Nigeria banking industry. Journal of Accounting and Management JAM vol, 4(1).

Lazaridis I and D Tryfonidis (2006). Relationship between Working Capital Management and Profitability of Listed Companies in the Athens Stock Exchange. Journal of Financial Management and Analysis 19 (1): 26-35.

Harford, J., S. Mansi, and W. Maxwell, 2005, corporate governance and firms' cash holdings, working paper, University of Washington, Seattle.

Modigliani, F., \& Miller, M. H. (1958). The cost of capital, corporation finance and the theory of investment. The American economic review, 48(3), 261-297.

Modigliani, F., and Miller, M. H. (1963). Corporate income taxes and the cost of capital: a correction. The American economic review, 53(3), 433-443.

Murugesu, T. (2013). Effect of debt on corporate profitability (Listed Hotel Companies Sri Lanka).European Journal of Business and Management, 5(30), 13-18.

Myers, S. C. (1984). The capital structure puzzle. The journal of finance, 39(3), 574-592.

Nazir, M. S., \& Afza, T. (2009). Impact of aggressive working capital management policy on firms' profitability. IUP Journal of Applied Finance, 15(8), 19.

Ozkan, A. (2001). Determinants of capital structure and adjustment to long run target: evidence from UK company panel data. Journal of Business Finance \& Accounting, 28(1-2), 175-198.

Padachi, K. (2006). Trends in working capital management and its impact on firms' performance: an analysis of Mauritian small manufacturing firms. International Review of business research papers, 2(2), 45-58.

Pinches, G. E., Mingo, K. A., and Caruthers, J. K. (1973). The stability of financial patterns in industrial organizations. The Journal of Finance, 28(2), 389-396.

Rajan, R. G. and Zingales, L. (1995). What do we know about capital structure: Some evidence from international data. Journal of Finance, 50(5), 1421-1460.

Shah, A., and Khan, S. 2007. Determinants of capital structure: Evidence from Pakistani panel data. International review of business research papers, 3(4), 265-282.

Smith MB and E Begemann (1997). Measuring Association between Working Capital and Return on Investment. South Africa Journal of Business Management 28(1): 1-5

Soenen L A (1993), "Cash Conversion Cycle and Corporate Profitability", Journal of Cash Management, Vol. 13, No. 4, pp. 53-58.

Teruel P J G and Solano P M (2005), "Effects of Working Capital Management on SME Profitability", International Journal of Managerial Finance, Vol. 3, No. 2, pp. 164-177.

Weinraub, H. J., \& Visscher, S. (1998). Industry practice relating to aggressive conservative working capital policies. Journal of Financial and Strategic Decision, 11(2), 11-18.

Zhang, Y., and Toppinen, A. (2011). Internationalization and financial performance in the global forest industry. International Forestry Review, 13(1), 96-105. 
Appendix

Table 4.1: Descriptive Statistics

\begin{tabular}{lllllll}
\hline Variables & Mean & Std. Dev. & Skewness & Kurtosis & Minimum & Maximum \\
\hline ROI & 0.068071 & 0.251620 & -2.116738 & 19.616974 & -2.08677 & 1.771462 \\
ROA & 0.041206 & 0.099530 & -3.234840 & 50.811686 & -1.65149 & 0.406255 \\
AIP & 0.462992 & 0.204154 & 0.177328 & -0.271240 & 0.000874 & 0.999594 \\
AFP & 0.375796 & 0.170659 & 0.072003 & -0.557938 & 0.000000 & 0.892639 \\
ROE & 0.127650 & 0.320601 & 0.243567 & 13.056689 & -1.95829 & 2.800278 \\
ROCE & 0.106261 & 0.229753 & 1.364374 & 18.466890 & -1.94783 & 2.319279 \\
GROWTH & 1.067346 & 0.585424 & 6.054620 & 56.659875 & 0.000000 & 8.369427 \\
SIZE & 6.479196 & 0.712418 & 0.091951 & 0.428504 & 3.841172 & 8.695685 \\
AGE & 1.438564 & 0.283940 & -2.050464 & 8.197873 & 0.000000 & 2.107210 \\
\hline
\end{tabular}

Table 4.2: Pearson Bivariate Correlations Analysis

\begin{tabular}{|c|c|c|c|c|c|c|c|c|c|c|}
\hline \multicolumn{2}{|c|}{ Description } & \multirow{2}{*}{$\frac{1}{1}$} & \multirow{2}{*}{$\frac{2}{.841}$} & & \multirow{2}{*}{$\frac{4}{-.053}$} & \multirow{2}{*}{$\frac{5}{.829}$} & \multirow{2}{*}{$\frac{6}{.744}$} & \multirow{2}{*}{$\begin{array}{l}7 \\
.089\end{array}$} & \multirow{2}{*}{$\frac{8}{.238}$} & \multirow{2}{*}{$\frac{9}{.045}$} \\
\hline ROI & Pearson & & & & & & & & & \\
\hline (1) & Sig & & .000 & .000 & .023 & .000 & .000 & .000 & .000 & .051 \\
\hline ROA & Pearson & .841 & 1 & .233 & -.150 & .684 & .729 & .098 & .268 & .103 \\
\hline (2) & Sig & .000 & & .000 & .000 & .000 & .000 & .000 & .000 & .000 \\
\hline AIP & Pearson & .189 & .233 & 1 & .422 & .205 & .285 & .071 & -.051 & -.018 \\
\hline (3) & Sig & .000 & .000 & & .000 & .000 & .000 & .002 & .027 & .432 \\
\hline AFP & Pearson & -.053 & -.150 & .422 & 1 & .026 & .029 & .059 & .028 & -.076 \\
\hline (4) & Sig & .023 & .000 & .000 & & .269 & .206 & .011 & .219 & .001 \\
\hline ROE & Pearson & .829 & .684 & .205 & .026 & 1 & .920 & .173 & .229 & .047 \\
\hline (5) & Sig & .000 & .000 & .000 & .269 & & .000 & .000 & .000 & .041 \\
\hline ROCE & Pearson & .744 & .729 & .285 & .029 & .920 & 1 & .183 & .234 & .081 \\
\hline (6) & Sig & .000 & .000 & .000 & .206 & .000 & & .000 & .000 & .000 \\
\hline GRTH & Pearson & .089 & .098 & .071 & .059 & .173 & .183 & 1 & .168 & -.016 \\
\hline (7) & Sig & .000 & .000 & .002 & .011 & .000 & .000 & & .000 & .502 \\
\hline SIZ & Pearson & .238 & .268 & -.051 & .028 & .229 & .234 & .168 & 1 & -.020 \\
\hline (8) & Sig & .000 & .000 & .027 & .219 & .000 & .000 & .000 & & .399 \\
\hline $\mathrm{AGE}$ & Pearson & .045 & .103 & -.018 & -.076 & .047 & .081 & -.016 & -.020 & 1 \\
\hline (9) & Sig & .051 & .000 & .432 & .001 & .041 & .000 & .502 & .399 & \\
\hline
\end{tabular}

Note: $*, * *$ and $* * *$ shows the significance level at $10 \%, 5 \%$ and $1 \%$ level of significance.

Table 4.3: Capital Structure Aggressiveness and Firm Performance (measured by ROI and ROA)

\begin{tabular}{lllllll}
\hline \multirow{2}{*}{ Variables } & Pooled & \multicolumn{3}{c}{ Fixed Effect } & \multicolumn{2}{c}{ Random Effect } \\
& ROI & ROA & ROI & ROA & ROI & ROA \\
\hline AIP & $0.120 * * *$ & $0.079 * * *$ & $0.291 * * *$ & $0.189 * * *$ & $0.126 * * *$ & $0.111 * * *$ \\
AFP & $-0.164 * * *$ & $-0.137 * * *$ & $-0.266 * * *$ & $-0.203 * * *$ & $-0.168 * * *$ & $-0.158 * * *$ \\
ROE & $0.766 * * *$ & $0.043 *$ & $0.680 * * *$ & $0.051 *$ & $0.760 * * *$ & $0.044 * * *$ \\
ROCE & -0.204 & $0.231 * * *$ & -0.253 & $0.154 * * *$ & $-0.205 * * *$ & $0.204 * * *$
\end{tabular}




$\begin{array}{lllllll}\text { GROWTH } & -0.025 * * * & -0.007 * * & -0.021 * * * & -0.009 * * * & -0.025 * * * & -0.009 * * * \\ \text { SIZE } & 0.027 * * * & 0.018 * * * & 0.167 * * * & 0.084 * & 0.028 * * * & 0.022 * * * \\ \text { AGE } & 0.006 & 0.014 * & -0.254 & -0.178 & 0.007 & 0.012 * \\ \text { Const } & -0.160 * * * & -0.107 * * & -0.721 * * * & -0.276 & -0.167 * * * & -0.134 * * * \\ \text { No. of Obs. } & 1869 & & & & & \\ \text { R }^{2} & 0.7083 & 0.5940 & 0.5191 & 0.4194 & 0.7083 & 0.5890 \\ \text { F (p-value) } & 645(0.00) & 388(0.00) & 245(0.00) & 164(0.00) & 4287(0.00) & 1958(0.00) \\ \text { Hausman (ROI) } & & 212.33(0.000) & & \\ \text { Hausman (ROA) } & & 934.94(0.000) & & \end{array}$

Note: $* * *$ and $* * *$ shows the significance level at $10 \%, 5 \%$ and $1 \%$ level of significance.

Table 4.4: Unit Root testing at Level (1) and First difference

\begin{tabular}{lllllll}
\hline & \multicolumn{2}{l}{ Levin-Lin-Chu } & \multicolumn{2}{l}{ Hadri LM Stationary } & \multicolumn{2}{l}{ Fisher ADF } \\
\hline Variables & Statistics & $p$-value & Statistics & $p$-value & Statistics & $p$-value \\
\hline ROI & -34.2511 & 0.0000 & 20.2354 & 0.0000 & 1878.79 & 0.0000 \\
D_ROI & $-5.4 \mathrm{e}+02$ & 0.0000 & 0.3135 & 0.3770 & 2565.62 & 0.0000 \\
ROA & -44.9769 & 0.0000 & 22.5098 & 0.0000 & 1805.37 & 0.0000 \\
D_ROA & -34.2511 & 0.0000 & 3.9294 & 0.0000 & 2481.35 & 0.0000 \\
AIP & -47.2540 & 0.0000 & 18.4439 & 0.0000 & 4046.45 & 0.0000 \\
D_AIP & $-1.3 \mathrm{e}+02$ & 0.0000 & 7.8984 & 0.0000 & 3136.55 & 0.0000 \\
AFP & $-4.4 \mathrm{e}+03$ & 0.0000 & 19.9799 & 0.0000 & 3358.00 & 0.0000 \\
D_AFP & $-6.6 \mathrm{e}+02$ & 0.0000 & 5.9114 & 0.0000 & 3170.63 & 0.0000
\end{tabular}

Table 4.5: Diagnostic Tests

\begin{tabular}{|c|c|c|}
\hline Descriptions & ROI & $\mathrm{ROA}$ \\
\hline Mean VIF & 2.83 & 2.83 \\
\hline $\begin{array}{l}\text { Breusch-Pagan / Cook- } \\
\text { Weisberg test for } \\
\text { heteroskedasticity }\end{array}$ & $\begin{array}{l}225.67 \\
(0.0000)\end{array}$ & $\begin{array}{l}254.99 \\
(0.0000)\end{array}$ \\
\hline $\begin{array}{l}\text { Breusch and Pagan } \\
\text { Lagrangian multiplier test for } \\
\text { random effects }\end{array}$ & $\begin{array}{l}9.92 \\
(0.0000)\end{array}$ & $\begin{array}{l}159.66 \\
(0.0000)\end{array}$ \\
\hline
\end{tabular}

For a matrix composed of the selected series:

const ROI ROA AIP AFP ROE ROCE Growth Size Lage

Condition number $=37.6908$

Collinearity check

A condition number greater than 50 is commonly regarded as indicating strong collinearity.

Diagram 1: Data Normality Diagram 


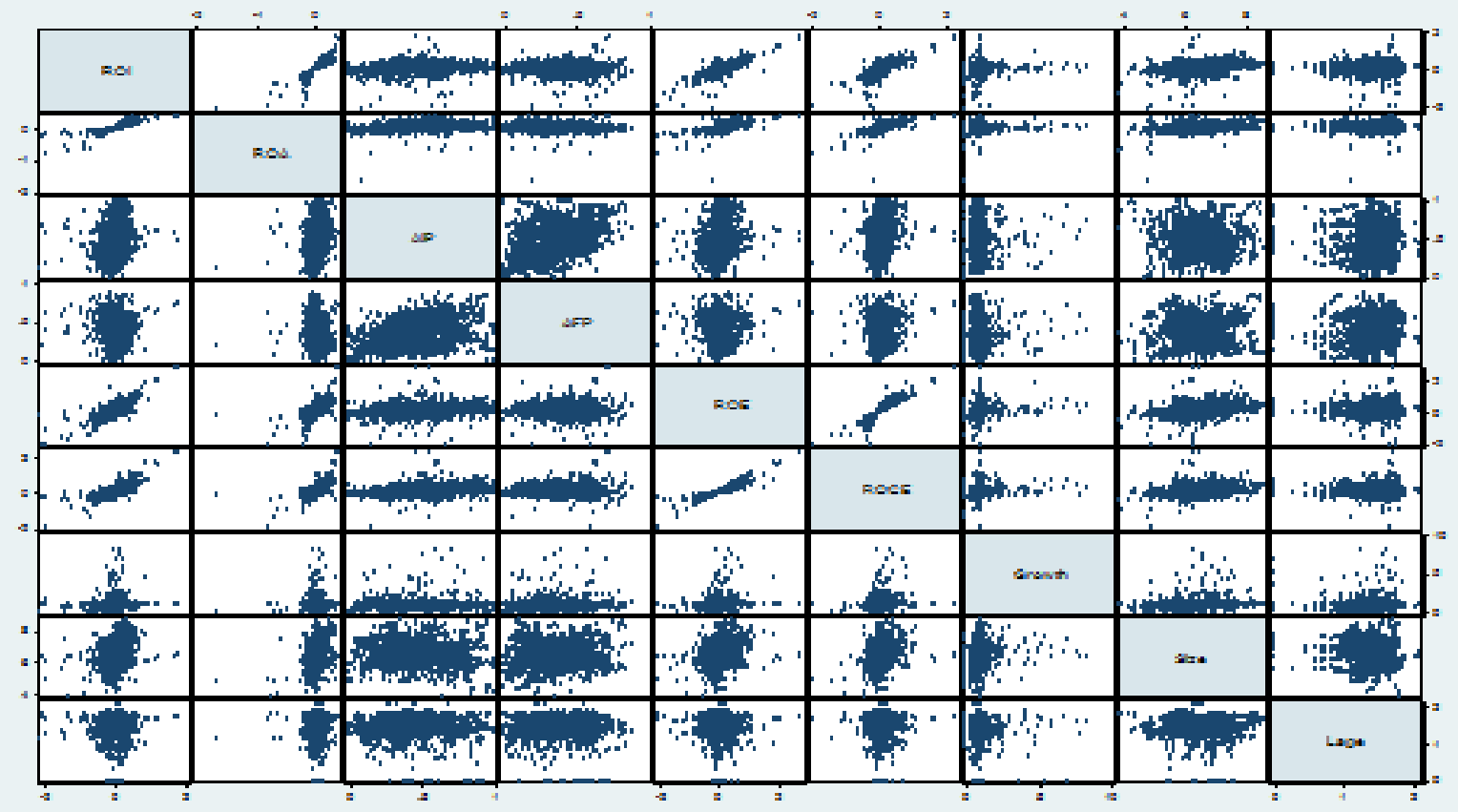

Diagram 2: Regression Line
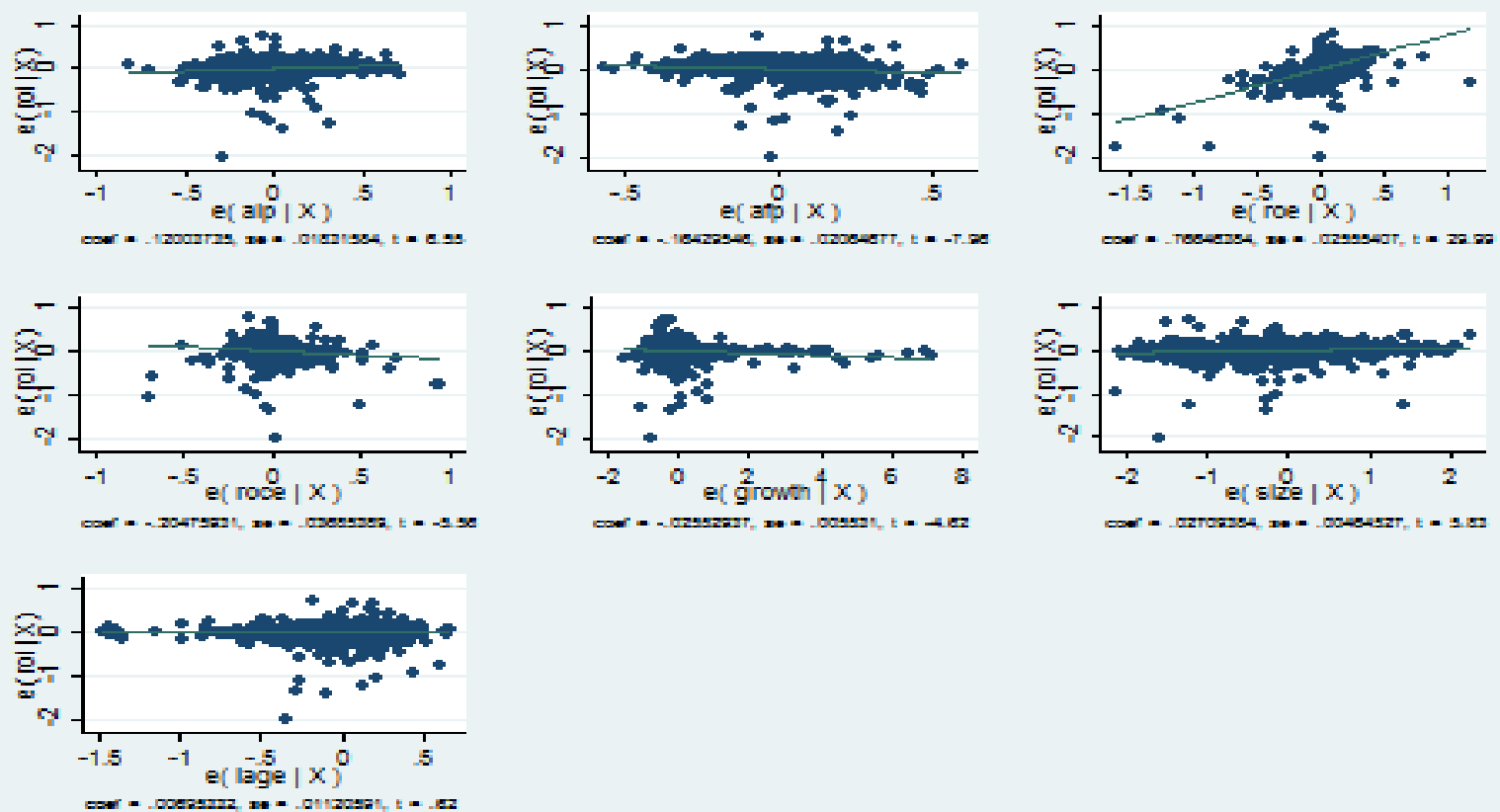


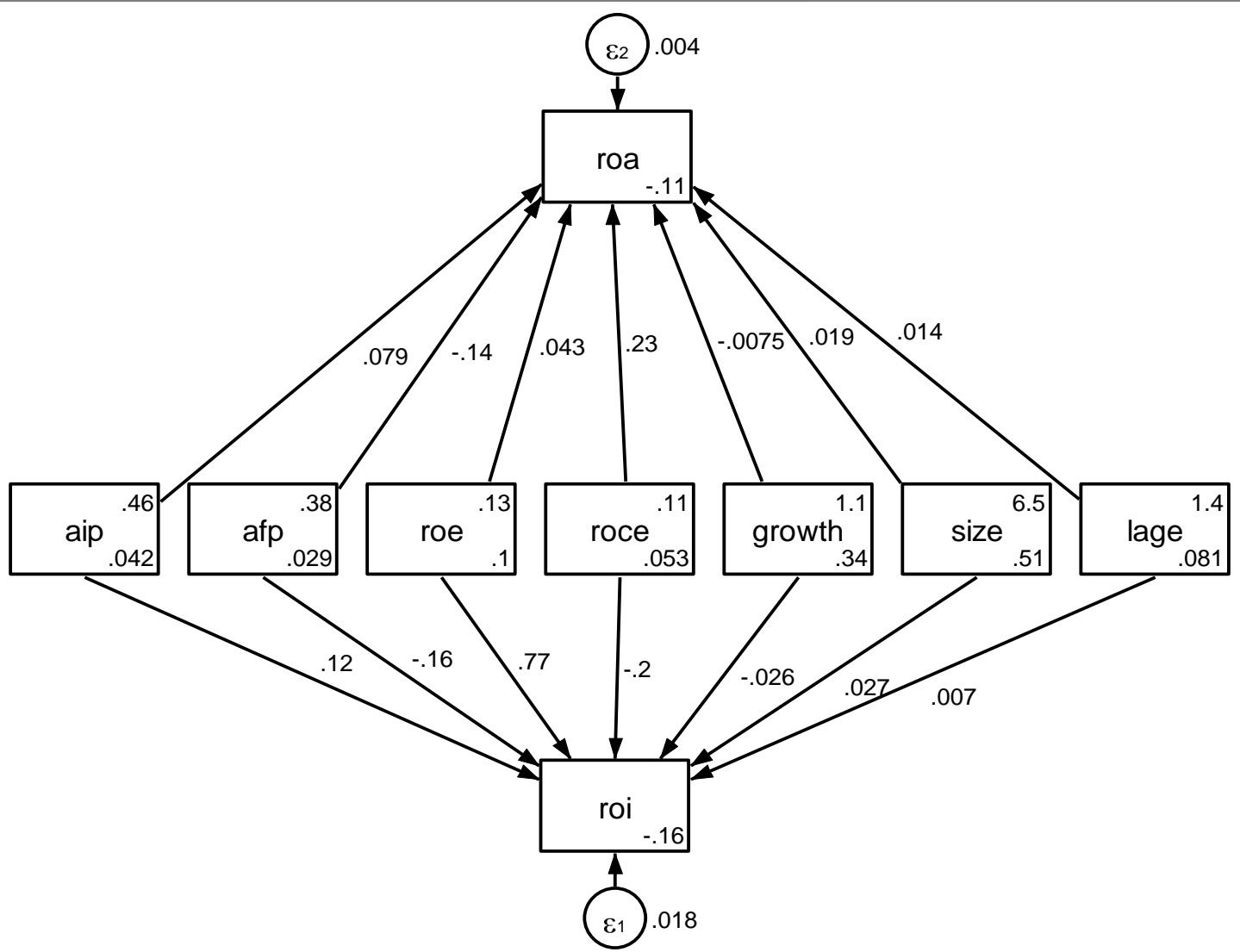

\section{Footnote}

ROI Return on Investments

ROA Return on Assets

AIP Aggressive Investment Policy

AFP Aggressive Financial Policy

ROE Return on Equity

ROCE Return on Capital Employed

GROWTH Firm's Growth

SIZE Firm's Size

AGE Firm's Age

EAT Earnings after Tax

PSX Pakistan Stock Exchange

GLS Generalized Least Square

OLS Ordinary Least Square

MM Modigliani and Miller

L Leverage

W Firm Value

ANOVA Analysis of variance and covariance

LSD Least Square Deviation 